Jurnal_ep, Vol. 9 No. 2, Agustus 2019

\title{
PENGARUH MODEL PEMBELAJARAN PROBLEM BASED LEARNING TERHADAP PENINGKATAN KOMUNIKASI DITINJAU DARI SIKAP KEMANDIRIAN MAHASISWI PRODI D III KEBIDANAN UNDIKSHA
}

\author{
Made Susi Lissia Andayani ${ }^{1}$, Ni Ketut Suarni ${ }^{2}$, I Nyoman Jampel ${ }^{3}$ \\ ${ }^{1}$ Jurusan Penelitian dan Evaluasi Pendidikan, ${ }^{2,3}$ Fakultas IImu Pendidikan \\ Universitas Pendidikan Ganesha \\ Singaraja, Indonesia \\ e-mail: feliciaartakirana90@gmail.com¹, \\ ketut.suarni@pasca.undiksha.ac.id²nyoman.jampel@pasca.undiksha.ac.id ${ }^{3}$,
}

\begin{abstract}
Abstrak
Penelitian pada mahasiswi D III Kebidanan Undiksha ini bertujuan untuk mengetahui: (1) pengaruh model pembelajaran Problem Based Learning (PBL) terhadap peningkatan komunikasi, (2) pengaruh sikap kemandirian tinggi dan sikap kemandirian rendah terhadap peningkatan komunikasi, dan (3) pengaruh interaksi model pembelajaran Problem Based Learning (PBL)dengan sikap kemandirian terhadap kemampuan komunikasi. Penelitian ini merupakan quasi experiment yang berbentuk pretest-posttest (one group pretest-posttest design). Populasi dalam penelitian ini adalah seluruh mahasiswa semester VI Prodi Kebidanan Undiksha sebanyak 79 orang. Data dalam penelitian dikumpulkan melalui pencatatan dokumen, kuesioner, dan observasi. Analisis data dalam penelitian dilakukan dengan metode deskriptif kuantitatif menggunakanteknik analisis varian (anova) dua jalur. Hasil penelitian pada mahasiswi D III Kebidanan Undiksha ini menunjukkan bahwa: (1) terdapat pengaruh antara model pembelajaran Problem Based Learning (PBL) dengan model konvensional terhadap peningkatan komunikasi mahasiswi, hal ini ditunjukkan dengan hasil perhitungan dimana $F_{\text {hitung }}(8.540)>F_{\text {tabel }}(3.11)$, (2) terdapat pengaruh sikap kemandirian tinggi dan sikap kemandirian rendah terhadap komunikasi mahasiswi yang ditunjukkan dengan hasil perhitungan dimana $F_{\text {hitung }}$ (85.544)> $F_{\text {tabel }}$ (3.11), dan (3) terdapat pengaruh interaksi yang signifikan antara model pembelajaran $\mathrm{PBL}$ dengan sikap kemandirian mahasiswi terhadap kemampuan komunikasi yang ditunjukkan dengan hasil perhitungan dimana $F_{\text {hitung }}(6.477)>$ $F_{\text {tabel }}(3.11)$.
\end{abstract}

Kata kunci: komunikasi, PBL, sikap kemandirian

\begin{abstract}
The study of Undiksha Midwifery Diploma III students aims to find out: (1) the effect of Problem Based Learning (PBL) learning models on improving communication, (2) the influence of high independence attitudes and low attitudes towards improving communication, and (3) the influence of model interactions learning Problem Based Learning (PBL) with an attitude of independence to communication skills. This research is quasi experiment. The population in this study were 79th semester students of Undiksha Midwifery Study Program. Data in the study were collected through recording documents, questionnaires, and observations. Data analysis in the study was carried out by quantitative descriptive method using two-way analysis of variance (ANOVA) techniques. The results of the Undiksha Midwifery Diploma III study showed that: (1) there was an influence between Problem Based Learning (PBL) and conventional models of communication improvement. student, this is indicated by the results of calculations where Fcount $(8,540)>$ Ftable $(3.11),(2)$ there is an influence of high independence attitude and low independence attitude towards student communication which is indicated by the calculation results where $F$ count $(85,544)>$ Ftable (3.11), and (3) there is a significant interaction effect between PBL learning models and student independence towards communication skills as indicated by the calculation results where $\mathrm{F}$ count (6.477)> Ftable (3.11).
\end{abstract}




\section{Keywords: communication, PBL, attitude of independence}

PENDAHULUAN

Pada era globalisasi seperti sekarang ini, Proses pembelajaran dewasa ini di perguruan tinggi lebih banyak mengarah pada aspek kognitif (ketrampilan teknis) dan kurang memperhatikan aspek non teknis mahasiswa. Indeks Prestasi Kumulatif (IPK) dinilai hanya sebagai gambaran kualitas mahasiswa dalam aspek kognitif saja. Hardskill dan softskill merupakan keterpaduan kompetensi dalam mewujudkan kualitas unggul dari mahasiswa yang harus terintegrasi dengan baik. Menurut Rilman (2013), "Hardskill adalah infrastruktur dan softskill adalah superstruktur, bangunan dikatakan lengkap apabila keduanya terjalin secara komplementer".

Tujuan pendidikan nasional mengisyaratkan bangsa Indonesia mencitacitakan akhlak mulia sebagai karakter dalam kehidupan berbangsa dan bernegara. Faktanya ada distorsi antara yang dicitacitakan dengan realitas praktek pendidikan. Menurut Mudlofir (2011:13), "pendidikan di Indonesia cenderung berorientasi berbasis hardskill (ketrampilan teknis) yang lebih banyak bertumpu pada Intelligence Quotient (IQ), namun kurang mengembangakan kemampuan Emotional Intelligence (EQ), dan Spiritual Intelligence (SQ)". Sedangkan hasil penelitian psikologi sosial dalam Elfindri, dkk (2013:68) menunjukkan orang yang sukses di dunia kerja ditentukan oleh peranan ilmu sebesar 18\%. Sisanya, $82 \%$ dijelaskan oleh ketrampilan emosional, softskill dan sejenisnya.

Pendidikan kebidanan berfungsi untuk menghasilkan tenaga bidan profesional meningkatkan daya saing bangsa melalui peningkatan softskill dengan peran yang sangat strategis, karena para lulusannya dipersiapkan bukan hanya untuk dapat terjun ke dunia kerja tetapi juga dipersiapkan untuk membantu mengatasi permasalahan kesehatan yang ada di masyarakat. Oleh karena itu, untuk ikut menyukseskan tujuan pendidikan nasional mahasiswa kebidanan selain dibekali dengan hardskill kebidanan juga harus dibekali dengan softskill yang memadai. Hal ini disebabkan karena softskill mutlak dibutuhkan di dunia kerja, baik ketika bidan bekerja di RS maupun di komunitas. Kemajuan dunia global yang pesat baik di bidang teknologi, informasi, pengetahuan, dan teknologi kesehatan termasuk kesehatan reproduksi berdampak pada adanya persaingan yang ketat dalam bidang kesehatan. Tuntutan masyarakat saat ini adalah pelayanan yang berkualitas, aman, nyaman dan terjangkau. Hal ini mendorong bidan untuk siap, tanggap serta mampu merespon dan mengantisipasi kemajuan zaman dan tuntutan masyarakat.

Undang-Undang RI No. 20 Tahun 2003 tentang Sistem Pendidikan Nasional Pasal 3 menyebutkan Pendidikan Nasional berfungsi untuk mengembangkan kemampuan dan membentuk karakter serta peradaban bangsa yang bermartabat dalam rangka mencerdaskan kehidupan bangsa. Pendidikan nasional bertujuan untuk mengembangkan potensi peserta didik agar menjadi manusia yang beriman dan bertakwa kepada Tuhan Yang Maha Esa, berakhlak mulia, sehat, berilmu, cakap, kreatif, mandiri, dan menjadi warga negara yang demokratis serta bertanggung jawab. Kemampuan yang dimaksud dalam UndangUndang RI No.20 Tahun 2003 yaitu kemampuan non teknis yang tentunya memiliki peran tidak kalah pentingnya dengan kemampuan akademik. Hasil survey National Association of Coleges and Employers (NACE) di AS diketahui bahwa keberhasilan lulusan Perguruan Tinggi berasal dari hal-hal yang sepele, hal-hal sepele tersebut adalah kemampuan yang tidak terlihat wujudnya (intangible) sehingga pendidikan di Perguruan Tinggi mulai digeser dari penguatan kemampuan tangible (terlihat wujudnya) ke intangible (tidak terlihat wujudnya). Kemampuan intangible tersebut biasa tertulis dalam lowongan pekerjaan dan saat ini sudah menjadi syarat pokok. Kemampuan intangible yang dimaksud yaitu kemampuan berkomunikasi, kemampuan bekerja sama dalam tim, berpenampilan menarik, dll. Bahkan terkadang suatu perusahaan memasang iklan dengan penjelasan "requite for attitude, train for skill" dengan alasan memberikan pelatihan keterampilan lebih mudah daripada membentukkan karakter. Kondisi ini menunjukkan begitu pentingnya 
kemampuan softskill harus dikuasi oleh lulusan Perguruan Tinggi untuk mampu bersaing di dunia kerja. Softskill sangat diperlukan keberadaannya mulai dari proses perekrutan atau seleksi karyawan hingga tentunya pada saat bekerja. Keseimbangan antara kemampuan hard skills dan softskill sangat diperlukan dalam dunia pekerjaan.

Mahasiswa kebidanan selain mempunyai dan menguasai keterampilan teknis kebidanan, juga harus mempunyai ilmu berkomunikasi yang tinggi. Pentingnya penguatan softskill ketika bidan memasuki dunia kerja menuntut lembaga pendidikan kebidanan merancang program pengembangan softskill dalam pembelajaran sebagai sarana membangun etika kerja dengan mahasiswa diikutkan dalam pembelajaran langsung dengan masyarakat. Dengan softskill yang baik, mahasiswa akan terampil dalam berkomunikasi, memimpin, membina hubungan dengan orang lain dan mengembangkan diri. Kecenderungan pelajaran yang diberikan di institusi pendidikan sebagian besar merupakan keterampilan teoritik. Hal tersebut berdasarkan kenyataan seperti yang disampaikan dalam Rakerwil Pimpinan PTS tahun 2013 bahwa di dalam sistem pendidikan saat ini $10 \%$ adalah softskill sedangakan $90 \%$ adalah hardskill (Santoso, 2014).

Hasil studi pendahuluan yang dilakukan di Prodi Kebidanan Undiksha didapatkan keterampilan komunikasi mata kuliah kebidanan mahasiswa semester VI $57 \%$ terkategori cukup, $27 \%$ terkategori nilai baik, dan $16 \%$ terkategori amat baik. Berdasarkan hasil wawancara yang dilakukan pada beberapa mahasiswa menyatakan bahwa mereka memiliki kesulitan dalam bersosialisasi dengan masyarakat yang menjadi desa binaan. Komunikasi merupakan elemen dasar dalam pengetahuan kebidanan dan salah satu yang paling penting dalam konsep kebidanan, karena hanya dengan komunikasi klien dapat secara jelas menyatakan kebutuhan dan keluhan tentang kesehatan (Sieger et al., 2012). Namun ada laporan dari penelitian terdahulu yang menyatakan mengenai rendahnya tingkat komunikasi antara bidan dan pasien
(Bowers et al, 2009), di antaranya adalah penelitian Whittington dan McLaughlin (2000) menyebutkan hanya 7\% dari waktu yang dihabiskan bidan dalam komunikasinya dengan pasien dan penelitian oleh Hurst et al. (2004) melaporkan hanya $4 \%$ dari waktu yang tersedia digunakan oleh bidan untuk berkomunikasi dengan pasien. Rendahnya tingkat komunikasi antara bidan dan pasien ini berbanding terbalik dengan kebijakan pusat audit Healthcare Commission yang memberikan waktu minimal 15 menit bagi bidan/perawat untuk berkomunikasi dengan pasien per shift kerja bidan atau perawat (Healthcare Commission, 2008).

Penelitian oleh Öztürk et al. (2013) menyebutkan bahwa $76 \%$ dari mahasiswa bidan mengalami masalah komunikasi ketika praktek di klinik. Mahasiswa bidan ini mengalami masalah komunikasi dengan bidan klinis sebanyak $68 \%$, pasien sebanyak $66 \%$, instruktur sebanyak $59 \%$, dan dokter sebanyak 44\%. Masalah komunikasi mereka disebabkan oleh pasien yang mengabaikan mereka sehingga tidak terjalin komunikasi yang efektif (59\%), oleh perawat klinis yang cenderung meremehkan mahasiswa (49\%), oleh dokter yang tidak ingin berkomunikasi dengan mereka (26\%), oleh instruktur (33\%) dan dengan sifat-sifat pribadi mereka sendiri (20\%). Praktek dan pelatihan dapat meningkatkan komunikasi dengan pasien dan membantu membangun hubungan yang lebih efektif dengan klien.

Kemampuan komunikasi berkembang bukan sekedar dari sebuah pengalaman. Telah banyak penelitian membuktikan bahwa keterampilan komunikasi yang baik diperoleh dari sebuah proses belajar yang khusus (Kurtz,et al,2005). Kemampuan komunikasi lebih baik diajarkan secara experiental learning, pembelajaran dikomunitas dapat memberikan suatu gambaran kepada mahasiswa mengenai masih kompleksnya masalah kesehatan, masalah lingkungan dan masalah sosial di komunitas perlunya bekerjasama dengan masyarakat melalui model pendidikan komunitas yang tepat untuk mendidik masyarakat dengan pemberdayaan mahasiswa. Fellety (2000) mengatakan bahwa suatu observasi di komunitas merupakan wahana untuk memahami 
masalah di komunitas. Mahasiswa dapat mengasah kemampuan berkomunikasi untuk lebih mengenal permasalahan. Pada kegiatan ini mahasiswa juga mendapat kesempatan bekerja sama dalam satu tim dan mengaplikasikan pengetahuan mereka kedalam kehidupan nyata, tidak hanya melalui demonstrasi dan pasien simulasi yang telah mereka dapatkan selama ini di skill lab.

Untuk mengasi permasalahan komunikasi di Prodi Kebidanan Undiksha, maka perlu diterapkan model pembelajaran yang dapat meningkatkan komunikasi mahasiswi. Salah satu alternatif yang dapat digunakan melalui model pembelajaran Problem Based Learning (PBL) atau juga biasa disebut dengan model pembelajaran berbasis masalah. Menurut Darmadi (2017:117) pembelajaran berbasis masalah merupakan sebuah pendekatan pembelajaran yang menyajikan masalah kontekstual sehingga merangsang peserta didik untuk belajar. Didalam kelas yang menerapkan model pembelajaran berbasis masalah, peserta didik bekerja dalam tim untuk memecahkan masalah dunia nyata. Masalah yang diberikan pada peserta didik ini digunakan untuk mengikat rasa ingin tahu pada pembelajaran yang dipelajari. Pembelajaran problem based learning didorong oleh tantangan, masalah nyata, dan peserta didik bekerja dalam kelompok kolaborasi kecil. Peserta didik didorong untuk bertanggungjawab terhadap kelompoknya dan mengorganisir proses pembelajaran dengan bantuan instruktur.

Menurut Hamdayama (2016:116) berpendapat bahwa model pembelajaran Problem Based Learning adalah pembelajaran yang memusatkan pada masalah kehidupan yang bermakna bagi peserta didik. Problem Based Learning memberikan kesempatan agar peserta didik dapat membiasakan diri beragumen atas setiap ide dan gagasannya. Pada PBM, peserta didik dihadapkan pada situasi atau masalah yang dapat mengantarnya untuk lebih mengenal objek permasalahan, melibatkan peserta didik melakukan proses pembelajaran secara aktif, mengemukakan kembali ide dalam membentuk pemahaman baru. Sehingga kecenderungan untuk meningkatnya kemampuan komunikasi menjadi lebih terbuka.

Berdasakan uraian diatas maka peneliti tertarik untuk melakukan penelitian yang berjudul "Pengaruh Model Pembelajaran Problem Based Learning terhadap Peningkatan Komunikasi Ditinjau dari Sikap Kemandirian Mahasiswi Prodi D III Kebidanan Undiksha".

\section{METODE}

Penelitian ini merupakan quasi experiment yang berbentuk pretest-posttest (one group pretest-posttest design). Populasi dalam penelitian ini adalah seluruh mahasiswa semester VI Prodi Kebidanan Undiksha sebanyak 79 orang. Data dalam penelitian dikumpulkan melalui pencatatan dokumen, kuesioner, dan observasi. Analisis data dalam penelitian dilakukan dengan metode deskriptif kuantitatif menggunakan teknik analisis varian (anova) dua jalur.

\section{HASIL DAN PEMBAHASAN}

\section{Hasil}

\section{Pengaruh Model Pembelajaran Problem Based Learning (PBL) terhadap Peningkatan Komunikasi pada Mahasiswi D III Kebidanan Undiksha}

Untuk menguji hipotesis yang menyatakan pengaruh penggunaan antara model Problem Based Learning (PBL) dengan model konvensional terhadap peningkatan komunikasi menggunakan analisis anava dua jalur berdasarkan perhitungan menggunakan program SPSS Statistics 17 diperoleh nilai Fhitung $=8.540$. Hasil perhitungan ini kemudian dibandingkan dengan Ftabel dengan taraf signifikan $\alpha=0.05$ sebesar 3.11. Dengan demikian $F_{\text {hitung }}(8.540)>F_{\text {tabel }}$ (3.11), sehingga dapat disimpulkan bahwa terdapat perbedaan pengaruh antara model pembelajaran Problem Based Learning (PBL) dengan model konvensional terhadap peningkatan komunikasi Mahasiswi. Berdasarkan hasil analisis data model pembelajaran Problem Based Learning (PBL) untuk kemampuan komunikasi memproleh rata-rata $($ mean $=18.759)$ lebih baik dari pada model pembelajaran 
konvensional dengan rata-rata nilai kemampuan komunikasi rata-rata (mean = 15,32).

\section{Pengaruh Sikap Kemandirian Tinggi dan Sikap Kemandirian Rendah terhadap Peningkatan Komunikasi pada Mahasiswi D III Kebidanan Undiksha}

Untuk menguji hipotesis pengaruh antara sikap kemandirian tinggi dan sikap kemandirian rendah terhadap komunikasi digunakan analisis anava dua jalur berdasarkan perhitungan statistik menggunakan program SPSS Statistics 17 diperoleh nilai Fhitung $=85.544$. hasil perhitungan ini kemudian dibandingkan dengan $F_{\text {tabel }}$ dengan taraf signifikan $\alpha=0.05$ atau sebesar 3.11. Dengan demikian $F_{\text {hitung }}$ (85.544) $>F_{\text {tabel }}$ (3.11), sehingga dapat disimpulkan bahwa terdapat pengaruh sikap kemandirian tinggi dan sikap kemandirian rendah terhadap komunikasi. Berdasarkan hasil analisis data sikap kemandirian tinggi untuk kemampuan komunikasi memproleh rata-rata (mean $=18,95)$ lebih baik dari pada sikap kemandirian rendah dengan rata-rata kemampuan komunikasi sebesar (mean = 17,67).

\section{Pengaruh Pembelajaran

$$
\text { Interaksi }
$$$$
\text { Problem }
$$ \\ Model \\ Learning (PBL) dengan Sikap Kemandirian terhadap Kemampuan Komunikasi Mahasiswi}

Untuk menguji hipotesis yang menyatakan pengaruh antara model pembelajaran Problem Based Learning (PBL) dengan sikap kemandirian terhadap kemampuan komunikasi mahasiswi digunakan analisis anava dua jalur. Berdasarkan perhitungan statistik menggunakan program SPSS Statistics 17 diperoleh nilai $F_{\text {hitung }}=6.477$ hasil perhitungan ini kemudian dibandingkan dengan $F_{\text {tabel }}$ dengan taraf signifikan $\alpha=0.05$ sebesar 3,11. Dengan demikian $F_{\text {hitung }}$ (6.477) $>F_{\text {tabel }}(3,11)$, sehingga dapat disimpulkan bahwa terdapat pengaruh interaksi yang signifikan antara model pembelajaran PBL dengan sikap kemandirian mahasiswi terhadap kemampuan komunikasi.

\section{Pembahasan}

Berdasarkan hasil analisis data yang telah dilakukan, maka didapatkan beberapa temuan dalam penelitian ini. Pertama penggunaan antara model Problem Based Learning (PBL) dan konvensional berpengaruh terhadap peningkatan kemampuan komunikasi mahasiswi D III Kebidanan Undiksha. Hal ini sesuai dengan hasil analisis anava dua jalur yang diperoleh menggunakan program SPSS Statistics 17 bahwa Fhitung (8.540) > Ftabel (3.11). Analisis yang telah dilakukan juga menunjukkan bahwa model pembelajaran Problem Based Learning (PBL) lebih baik dalam meningkatkan kemampuan komunikasi mahasiswi dimana rata-rata nilai mahasiswi yang dibelajarkan dengan model PBL mencapai 18,759 sedangkan mahasiswi yang dibelajarkan dengan model konvensional hanya memperoleh rata-rata nilai kemampuan komunikasi sebesar 15,32. Hasil yang diperoleh di atas, menunjukkan bahwa model pembelajaran PBL lebih efektif dalam meningkatkan kemampuan komunikasi mahasiswi. Hal ini disebabkan oleh model pembelajaran PBL yang lebih menekankan dan memberikan kesempatan kepada mahasiswi untuk beragumen atas setiap ide dan gagasannya dalam menghadapi setiap permasalahan yang dihadapi. Selain itu, dalam pembelajaran yang menerapkan model PBL mahasiswi dilibatkan secara aktif mengemukakan kembali ide dalam membentuk pemahaman baru. Sehingga kecenderungan untuk meningkatnya kemampuan komunikasi menjadi lebih terbuka. Pendapat tersebut sejalan dengan Hamdayama (2016:116) yang menyatakan bahwa model Problem Based Learning merupakan model pembelajaran yang memusatkan pada masalah kehidupan yang bermakna bagi dan memberikan kesempatan agar peserta didik dapat membiasakan diri beragumen atas setiap ide dan gagasannya.

Selain mampu meningkatkan
kemampuan mahasiswi dalam
berkomunikasi, model pembelajaran PBL
juga mampu merangsang mahasiswi untuk 
belajar dan bekerjasama dalam memecahkan masalah. Masalah yang dijadikan pembelajaran berhubungan dengan kenyataan yang dialami oleh mahasiswi. Masalah yang diberikan pada mahasiswi ini digunakan untuk mengikat rasa ingin tahu pada pembelajaran yang dipelajari. Hal tersebut sesuai dengan pendapat Darmadi (2017:117) yang menyatakan pembelajaran Problem Based Learning didorong oleh tantangan, masalah nyata, dan peserta didik bekerja dalam kelompok kolaborasi kecil. Peserta didik didorong untuk bertanggungjawab terhadap kelompoknya dan mengorganisir proses pembelajaran dengan bantuan instruktur.

Hal sebaliknya terjadi ketika mahasiswi dibelajarkan model pembelajaran konvensional. Pembelajaran konvensional yang lebih banyak dilakukan melalui ceramah, tanya jawab dan penugasan yang berlangsung secara terus menerus membuat aktivitas mahasiswi dalam pembelajaran sangat terbatas. Mahasiswi hanya mendengarkan penjelasan dari dosen dan pasif dalam pembelajaran. Pendapat tersebut senada dengan Arvianto (2011) dalam penelitiannya yang menyatakan bahwa dalam pembelajaran yang bersifat konvensional peserta didik diposisikan sebagai objek pembelajaran, sehingga proses pembelajaran tidak dapat berlangsung dengan optimal. Pembelajaran yang bersifat konvensional juga membuat mahasiswi cepat merasa bosan. Hal ini dapat menghambat pemahaman konsep mahasiswi dalam pembelajaran. Pemahaman mahasiswi terhadap suatu materi atau konsep dalam pembelajaran, tentunya berpengaruh terhadap kemampuan mahasiswi dalam berkomunikasi. Jika mahasiswi tidak mampu memahami materi pelajaran dengan baik, maka mereka akan mengalami kesulitan dalam mengkomunikasikan ide maupun gagasannya.

Kedua, terdapat pengaruh antara sikap kemandirian tinggi dan sikap kemandirian rendah terhadap komunikasi. Kesimpulan ini diperoleh berdasarkan analisis anava dua jalur menggunakan program SPSS Statistics 17 diperoleh nilai Fhitung $=85.544$. Hasil perhitungan ini kemudian dibandingkan dengan Ftabel dengan taraf signifikan $\alpha=0.05$ atau sebesar 3.11. Dengan demikian Fhitung (85.544) > Ftabel (3.11). Analisis yang telah dilakukan juga menunjukkan bahwa sikap kemandirian tinggi lebih baik dibandingkan sikap kemandirian rendah yang dimiliki mahasiswi dalam meningkatkan kemampuan komunikasi. Rata-rata nilai komunikasi yang diperoleh oleh mahasiswi yang memiliki sikap kemandirian tinggi mencapai 18.95, sedangkan pada mahasiswi yang memiliki sikap kemandirian rendah nilai rata-rata kemampuan komunikasi sebesar 17,67.

Perbedaan nilai rata-rata kemampuan komunikasi antara mahasiswi yang memiliki sikap kemandirian tinggi dan mahasiswi yang memiliki sikap kemandirian rendah menunjukkan bahwa sikap kemandirian merupakan aspek yang penting dalam komunikasi. Hal ini sesuai dengan pendapat yang dikemukakan oleh Haroen (2015) yang menyatakan bahwa sikap kemandirian yang terdapat pada diri peserta didik menjadi faktor utama untuk pencapaian komunikasi dan prestasi belajar yang baik. Artinya, peserta didik perlu memiliki kesadaran, kemauan, dan motivasi dari dalam diri peserta didik untuk berbuat, bertindak, dan berpikir atas dasar kreatif dan penuh inisiatif, percaya diri, bertanggung jawab, dan bukan semata-mata tekanan dari pihak lain. Hal senada juga dikemukkan oleh Nursobah (2009) yang menyatakan bahwa salah satu hal yang dapat mempengaruhi kemampuan komunikasi adalah sikap kemandirian. Dengan adanya sikap kemandirian dari dalam diri, maka akan ada dorongan bagi peserta didik untuk berkomunikasi secara aktif untuk mengemukakan ide dan gagasannya. Berdasarkan kedua pendapat tersebut, maka dapat disimpulkan bahwa sikap kemandirian akan mendorong peserta didik untuk berkomunikasi secara aktif dan lebih baik dari pada mahasiswi yang tidak memiliki sikap kemandirian.Semakin tinggi sikap kemandirian yang dimiliki oleh seseorang, maka semakin tinggi juga dorongan yang dimiliki untuk berkomunikasi. Sebaliknya, semakin rendah sikap kemandirian yang dimiliki maka semakin rendah pula dorongan berkomunikasi yang dimiliki. 
Ketiga, terdapat interaksi yang signifikan antara model pembelajaran PBL dengan sikap kemandirian mahasiswi terhadap kemampuan komunikasi. Kesimpulan tersebut diperoleh berdasarkan perhitungan statistik menggunakan program SPSS Statistics 17 dimana nilai Fhitung $(6.477)>$ Ftabel $(3,11)$. Adanya interaksi yang signifikan dalam penerapan model pembelajaran $\mathrm{PBL}$ dengan sikap kemandirian disebabkan oleh model PBL yang menekankan kepada proses penyelesaian masalah yang dihadapi secara ilmiah. Dengan model pembelajaran ini mahasiswi diajak untuk berpikir terhadap suatu permasalahan yang dihadapi dan berkaitan dengan kondisi nyata atau permasalahan yang ada dalam kehidupan sehari-hari.

Mahasiswi yang mempunyai sikap kemandirian tinggi akan memiliki pengaruh yang signifikan dalam meningkatkan kemampuan komunikasi. Hal ini sejalan dengan pendapat Nursobah (2009) yang menyatakan bahwa salah satu hal yang dapat mempengaruhi kemampuan komunikasi adalah sikap kemandirian. Mahasiswi yang mimiliki sikap kemandirian tinggi akan memiliki rasa ingin tahu yang tinggi, rasa percaya diri, dan kesadaran diri, sehingga akan memunculkan dorongan untuk berkomunikasi secara aktif dalam memecahkan permasalahan yang dihadapi saat pembelajaran. Dengan menggunakan model PBL dan sikap kemandirian yang tinggi, maka mahasiswi akan dapat berkomunikasi dengan baik. Sebaliknya Mahasiswi yang mimiliki sikap kemandirian tinggi rendah memiliki rasa ingin tahu yang rendah, sehingga sulit memunculkan dorongan untuk berkomunikasi secara aktif dalam memecahkan permasalahan yang dihadapi saat pembelajaran.

\section{PENUTUP}

Berdasarkan hasil penelitian dan pembahasan di atas, dapat disimpulkan sebagai berikut.(1) terdapat pengaruh model pembelajaran Problem Based Learning $(\mathrm{PBL})$ terhadap peningkatan komunikasi mahasiswi D III Kebidanan Undiksha yang ini ditunjukkan dengan Fhitung (8.540)>Ftabel (3.11). Analisis yang telah dilakukan juga menunjukkan bahwa model pembelajaran Problem Based Learning (PBL) lebih baik dalam meningkatkan kemampuan komunikasi mahasiswi dimana rata-rata nilai mahasiswi yang dibelajarkan dengan model PBL mencapai 18,759 sedangkan mahasiswi yang dibelajarkan dengan model konvensional hanya memperoleh rata-rata nilai kemampuan komunikasi sebesar 15,32. (2) terdapat pengaruh antara sikap kemandirian tinggi dan sikap kemandirian rendah terhadap komunikasi mahasiswi D III Kebidanan Undiksha yang ini ditunjukkan dengan Fhitung (85.544) > Ftabel (3.11). Analisis yang telah dilakukan juga menunjukkan bahwa sikap kemandirian tinggi lebih baik dibandingkan sikap kemandirian rendah yang dimiliki mahasiswi dalam meningkatkan kemampuan komunikasi. Rata-rata nilai komunikasi yang diperoleh oleh mahasiswi yang memiliki sikap kemandirian tinggi mencapai 18.95, sedangkan pada mahasiswi yang memiliki sikap kemandirian rendah nilai rata-rata kemampuan komunikasi sebesar 17,67., dan (3) terdapat interaksi yang signifikan antara model pembelajaran PBL dengan sikap kemandirian mahasiswi terhadap kemampuan komunikasi mahasiswi D III Kebidanan Undiksha yang ini ditunjukkan dengan. nilai Fhitung $(6.477)>$ Ftabel $(3,11)$.

Saran yang dapat disampaikan berdasarkan penelitian yang telah dilakukan adalah sebagai berikut. (1.) disarankan kepada mahasiswi D III Kebidanan Undiksha, agar dapat meningkatkan sikap kemandirian, sehingga dapat meningkatkan kemampuan komunikasi, dan (2) disarankan kepada dosen yang mengajar di D III Kebidanan Undiksha, agar dapat meningkatkan sikap kemandirian dan menggunakan model pembelajaran inovatif seperti PBL, sehingga dapat meningkatkan kemampuan komunikasi mahasiswi.

\section{DAFTAR RUJUKAN}

Astuti WD, Budijanto D. Kemampuan soft skill sumber daya manusia kesehatan di Kabupaten Bojonegoro dan Magetan provinsi Jawa Timur. Jurnal Manajemen Pelayanan Kesehatan. 2009;12(4):193-8 
Azwar, S.(2012). Reliabiltas dan Validitas. Yogyakarta: Penerbit Liberty.

Basrowi. 2007. Metode Analisis Data Sosial. Kediri: CV. Jenggala Pustaka Utama.

Graeff JA, Elder JP, Booth EM. Comunication for health and behavior. Yogyakarta: Gadjah Madauniversity press; 2016

Herizon, Wirda F. (2012). Pengembangan soft skills melalui pendekatan student center learning di perguruan tinggi. Polibisnis. 2012;4(2).

Hergenhahn BR, Olson OMH. Theories of learning (Teori Belajar).7, editor. Jakarta: Kencana Prenada media Group; 2008

HPEQ. Draft Standar Kompetensi Bidan Indonesia 26 November 2013

Kelly L, Walters L, Rosenthal D. Community based medical education: Is success a result of meaningful personal learning experiences? Education for Health. 2014;27(1).

Kesuma D, Triatna C, Permana J. Pendidikan karakter: kajian teori dan praktek di sekolah. Bandung: PT Remaja Rosdakarya; 2012

Koesno H. Bidan yang berkarakter. Bidan (Media Komunikasi Bidan \&Keluarga Indonesia).2009.

Lee $\mathrm{KH}$. Nurse Midwifery education throught graduate programs to provide a sufficient number of high quality nurse. Journal of Education Evaluation for Health Proffesions.2013;3

Masanobu Okayama. Community based Medical Education. General medicine. 2014
Mennin S, Mennin RP. Comunity based medical education. The clinical teacher. 2014

Santoso. 2014. Integrasi Softskill di Perkuliahan: Langkah Lebih Pengembangan dan Pendekatan Pendidikan di Perguruan Tinggi. (Online). Tersedia pada http://slametsantoso.multiply.co m.html. (diakses tanggal, 4 Pebruari 2019).

Santrock JW. Psikologi pendidikan. 2,editor. Jakarta: Kencana;2008

Sarfraz M, Hamid S. (2014). Challenges in delivery of skilled maternal care experiences of community midwives in Pakistan. BMC Pregnancy and Childbirth

Sailah I. (2008). Pengembangan soft skills di Perguruan Tinggi 2008. Available from: http://isailah.50webs.com/Buku Pengembangan Soft Skills 2008. Pdf

Sugiyono. Metode penelitian kuantitatif, kualitatif dan kombinasi (Mixed method). 2 ed. Bandung: Alfabeta. 